\title{
Large cell neuroendocrine carcinoma of the head and neck: a distinct clinicopathologic entity
}

\author{
Alfio Ferlito • Primož Strojan • James S. Lewis Jr. • \\ Bayardo Perez-Ordoñez $\cdot$ Alessandra Rinaldo
}

Received: 22 March 2014 / Accepted: 6 May 2014 / Published online: 15 May 2014

(C) Springer-Verlag Berlin Heidelberg 2014

Head and neck cancers account for approximately five percent of all cancers, and the majority are squamous cell carcinoma. Neuroendocrine carcinomas of the head and neck are uncommon and present unique challenges both in diagnosis and treatment. Tumors with neuroendocrine morphology are a distinct subset of neoplasms that share specific morphologic, histochemical, immunohistochemical, ultrastructural, and molecular characteristics. These tumors include paraganglioma, well-differentiated neuroendocrine carcinoma (or typical carcinoid), moderately differentiated neuroendocrine carcinoma (or atypical carcinoid), small cell neuroendocrine carcinoma (SCNC), and large cell neuroendocrine carcinoma (LCNC). Staging, treatment, and prognosis vary widely among the five neuroendocrine

This paper was written by members of the International Head and Neck Scientific Group (www.IHNSG.com).

A. Ferlito $(\bowtie) \cdot$ A. Rinaldo

University of Udine School of Medicine, Piazzale S. Maria della

Misericordia, 33100 Udine, Italy

e-mail: a.ferlito@uniud.it

P. Strojan

Department of Radiation Oncology, Institute of Oncology,

Ljubljana, Slovenia

\section{J. S. Lewis Jr.}

Department of Pathology and Immunology

and Otolaryngology-Head and Neck Surgery, Washington

University School of Medicine, St. Louis, MO, USA

\section{B. Perez-Ordoñez}

Department of Pathology, Toronto General Hospital, University

Health Network, Toronto, ON, Canada

B. Perez-Ordoñez

Department of Laboratory Medicine and Pathobiology,

University of Toronto, Toronto, ON, Canada neoplasms of the head and neck, thus accurate histologic classification is essential.

LCNC is a high-grade malignant neuroendocrine tumor that was first defined in the lungs by Travis et al. [1] in 1991. This tumor accounts for approximately $3 \%$ of all lung cancers [2], and the prognosis is poor. The diagnosis of LCNC is based on high-grade features, and the presence of both neuroendocrine morphology as well as immunohistochemical evidence of neuroendocrine differentiation. LCNC is a poorly differentiated neuroendocrine neoplasm that has several morphological and biologic features in common with both moderately differentiated neuroendocrine carcinoma (atypical carcinoid) and SCNC. However, the prognosis of pulmonary LCNC and SCNC is significantly worse than for moderately differentiated neuroendocrine carcinoma.

The 2005 World Health Organization Classification of Head and Neck Tumours [3] was a significant step towards diagnostic standardization of head and neck neuroendocrine carcinomas. It did not specifically include LCNC as a distinct tumor type, however. In the last 10 years, though, there have been new data supporting the recognition of "large cell neuroendocrine carcinoma" as a distinctive high-grade carcinoma in the head and neck, an entity not included in the 2005 Classification [4]. By the 2005 WHO classification, laryngeal LCNCs would actually be classified as variants of moderately differentiated neuroendocrine carcinoma (atypical carcinoid), whereas the pulmonary WHO classification considers LCNCs as poorly differentiated neuroendocrine carcinomas essentially grouping them with SCNC. The proper distinction among these entities is of paramount importance as it has significant therapeutic and prognostic implications.

The first report of LCNC in the head and neck was published by Hui et al. [5] in 1990 and at that time the authors 
used the term undifferentiated carcinoma. As a highly aggressive malignancy, this tumor attracts a significant attention and is in focus of considerable discussion recently also in head and neck area [6-17].

There are reports of these tumors arising in a variety of the head and neck subsites, the most common being the larynx [14, 17-24]. The parotid gland is the second most common site $[5,11,12,25]$. LCNCs are increasingly being recognized in other sites and have been reported in sinonasal tract [9, 26], oral cavity [27], oropharynx [8, 28], hypopharynx [8], and submandibular gland [10, 29]. Given the limitations of the current WHO classification, which does not make a distinction between moderately differentiated neuroendocrine carcinoma and LCNC, a reliable estimate of the true incidence of LCNC is not possible.

Macroscopically, the tumor presents as a submucosal unencapsulated mass. The tumor cells have relatively abundant, eosinophilic cytoplasm and a neuroendocrine architecture (organoid nesting, palisading, trabecular growth and/or rosette-like structures). Their nuclei display coarse or fine chromatin, frequently having a "salt and pepper" appearance as in other neuroendocrine tumors, and usually also have prominent nucleoli. The tumor often shows large areas of coagulative necrosis, and by definition, has a high mitotic rate ( $>10$ mitotic figures in $2 \mathrm{~mm}^{2}$ of viable tumor). The cells are positive for one or more neuroendocrine markers (synaptophysin, chromogranin A, CD56) other than neuron-specific enolase. The tumor may be immunopositive for thyroid transcription factor. Cytokeratin subsets are of limited utility in diagnosing this tumor. Immunohistochemistry for Ki-67 usually shows a very high proliferative fraction. Electron microscopy shows numerous neurosecretory granules in the cytoplasm of the cells.

LCNC has to be distinguished from SCNC and moderately differentiated neuroendocrine carcinoma. The differential diagnosis may be difficult in small biopsies and can be especially challenging in cytologic specimens. Currently there is no immunohistochemical stain for discrimination between SCNC, moderately differentiated neuroendocrine carcinoma, and LCNC. The major feature that distinguishes between LCNC and moderately differentiated neuroendocrine carcinoma is the mitotic activity which is very abundant in LCNC, being defined specifically in the lung as $>10$ mitoses per ten high-power fields, whereas moderately differentiated neuroendocrine carcinoma is between two and ten mitoses per ten high-power fields. The neoplastic cells are generally small in SCNC and large in LCNC. However, the critical distinction is not in the overall cell size, but in the nuclear to cytoplasmic ratios ("high" in small cell and "lower" in large cell). In an attempt to differentiate between SCNC and LCNC, a panel of three markers, BAI3, CDX2, and VIL1, was suggested as an adjunct in the distinction amongst these tumor subtypes [30].
In a recent meta-analysis on the neuroendocrine carcinoma of the larynx by van der Laan et al. [14], median age of the LCNC patients was found comparable to those with SCNC, although the proportion of female patients was somewhat larger in the former group (29.6 vs. $18.6 \%$ ). In addition, median duration of symptoms, history of tobacco smoking, and stage distribution were also similar between the two. Significantly more supraglottic primaries (81.5 vs. $57.9 \%$ ) have been reported in LCNC of the head and neck than for SCNC [14], and no association with paraneoplastic syndromes has been reported for LCNC.

The treatment of LCNC is controversial and not standardized, even when it occurs in the lung [15]. Because of its rarity of LCNC in head and neck, there are no clinical trials that define the optimal treatment approach for either localized or advanced disease.

In above cited meta-analysis with 29 laryngeal LCNC included, the 5 years disease-specific survival was $15.3 \%$ for LCNC, the worst among all four histological subtypes from the neuroendocrine tumor group (typical carcinoids $100 \%$, atypical carcinoids $52.8 \%$, small cell neuroendocrine tumors $19.3 \%$ ) [14]. When treatment results between SCNC and LCNC were compared, regional control (84 vs. $34.6 \%$ ) and distant-metastasis free survival ( 46.5 vs. $34.7 \%$ ) at 5 years were worse in the LCNC patients, whereas local control seemed comparable between the two (91.6 vs. $88.2 \%$ ). However, when SCNC and LCNC were analyzed by the treatment that was used, it appears that in patients with LCNC, chemotherapy was administered significantly less frequently and that a larger proportion of these patients had only locoregional treatment, i.e. surgery, radiotherapy or combination of the two (75 vs. $42 \%$ ). In tumors with high propensity for distant dissemination, like LCNC, shortage of chemotherapy implementation could be one of the reasons for poor treatment results and short survival [14] in the current literature.

Some authors believe that a treatment approach similar to that of SCNC of the lung may be indicated. However, there is no standardized therapy, even in lung LCNC. Combined cisplatin-based chemotherapy, similar to the one used for small-cell counterpart, seems to be most effective [31]. For LCNC of the head and neck, aggressive trimodality therapy seems to be the most effective treatment option although survival remains poor. In these tumors, surgery supplemented with postoperative radiotherapy or concomitant chemoradiotherapy is accepted as the primary treatment modality for localized disease. It appears that in all but the most early-stage tumors, some forms of systemic therapy acting against possible micrometastases should be part of the treatment regimen. For patients with systemic disease, palliative chemotherapy or best supportive care remain appropriate options. 


\section{References}

1. Travis WD, Linnoila RI, Tsokos MG, Hitchcock CL, Cutler GB Jr, Nieman L, Chrousos G, Pass H, Doppman J (1991) Neuroendocrine tumors of the lung with proposed criteria for large-cell neuroendocrine carcinoma. An ultrastructural, immunohistochemical, and flow cytometric study of 35 cases. Am J Surg Pathol 15:529-553

2. Takei H, Asamura H, Maeshima A, Suzuki K, Kondo H, Niki T, Yamada T, Tsuchiya R, Matsuno Y (2002) Large cell neuroendocrine carcinoma of the lung: a clinicopathologic study of eightyseven cases. J Thorac Cardiovasc Surg 124:285-292

3. Barnes L (2005) Neuroendocrine tumors. In: Barnes L, Eveson JW, Reichart P, Sidransky D (eds) WHO classification of tumours. Pathology and genetics of head and neck tumours. IARC Press, Lyon, pp 135-139

4. Xu B, Chetty R, Perez-Ordoñez B (2014) Neuroendocrine neoplasms of the head and neck: some suggestions for the new WHO classification of head and neck tumors. Head Neck Pathol 8:24-32

5. Hui KK, Luna MA, Batsakis JG, Ordóñez NG, Weber R (1990) Undifferentiated carcinomas of the major salivary glands. Oral Surg Oral Med Oral Pathol 69:76-83

6. Devaney KO, Ferlito A, Rinaldo A (2010) Neuroendocrine carcinomas of the larynx: what do the different histologic types really mean? Eur Arch Otorhinolaryngol 267:1323-1325

7. Chetty R, Shah KA, Perez-Ordonez B (2012) Large cell neuroendocrine carcinoma of the head and neck. Am J Surg Pathol 36:1102-1103

8. Kusafuka K, Abe M, Iida Y, Onitsuka T, Fuke T, Asano R, Kamijo T, Nakajima T (2012) Mucosal large cell neuroendocrine carcinoma of the head and neck regions in Japanese patients: a distinct clinicopathological entity. J Clin Pathol 65:704-709

9. Kao HL, Chang WC, Li WY, Chia-Heng Li A, Fen-Yau Li A (2012) Head and neck large cell neuroendocrine carcinoma should be separated from atypical carcinoid on the basis of different clinical features, overall survival, and pathogenesis. Am J Surg Pathol 36:185-192

10. Yamamoto N, Minami S, Kidoguchi M, Shindo A, Tokumaru Y, Fujii M (2014) Large cell neuroendocrine carcinoma of the submandibular gland: case report and literature review. Auris Nasus Larynx 41:105-108

11. Nagao T, Sugano I, Ishida Y, Tajima Y, Munakata S, Asoh A, Yamazaki K, Muto H, Konno A, Kondo Y, Nagao K (2000) Primary large-cell neuroendocrine carcinoma of the parotid gland: immunohistochemical and molecular analysis of two cases. Mod Pathol 13:554-561

12. Casas P, Bernáldez R, Patrón M, López-Ferrer P, García-Cabezas MA (2005) Large cell neuroendocrine carcinoma of the parotid gland: case report and literature review. Auris Nasus Larynx 32:89-93

13. Kusafuka K, Ferlito A, Lewis JS Jr, Woolgar JA, Rinaldo A, Slootweg PJ, Gnepp DR, Devaney KO, Travis WD, Barnes L (2012) Large cell neuroendocrine carcinoma of the head and neck. Oral Oncol 48:211-215

14. van der Laan TP, Plaat BE, van der Laan BF, Halmos GB (2014) Clinical recommendations on the treatment of neuroendocrine carcinoma of the larynx - a meta-analysis of 436 reported cases. Head Neck [Epub ahead of print]

15. Ferlito A, Lewis JS Jr, Rinaldo A (2011) The evolving management of laryngeal neuroendocrine carcinomas. Eur Arch Otorhinolaryngol 268:1247-1248
16. Lewis JS Jr, Ferlito A, Gnepp DR, Rinaldo A, Devaney KO, Silver CE, Travis WD (2011) Terminology and classification of neuroendocrine neoplasms of the larynx. Laryngoscope 121:1187-1193

17. van der Laan TP, van der Laan BF, Plaat BE, Wedman J, Van Hemel BM, Halmos GB (2012) Neuroendocrine carcinoma of the larynx: an extraordinary malignancy with high recurrence rates and long survival: our experience in 11 patients. Clin Otolaryngol 37:63-66

18. Chung JH, Lee SS, Shim YS, Kim SY, Nam SY, Kim DH, Cho KJ (2004) A study of moderately differentiated neuroendocrine carcinomas of the larynx and an examination of non-neoplastic larynx tissue for neuroendocrine cells. Laryngoscope 114:1264-1270

19. Greene L, Brundage W, Cooper K (2005) Large cell neuroendocrine carcinoma of the larynx: a case report and a review of the classification of this neoplasm. J Clin Pathol 58:658-661

20. Patel KJ, Chandana SR, Wiese DA, Olsen B, Conley BA (2010) Unusual presentation of large-cell poorly differentiated neuroendocrine carcinoma of the epiglottis. J Clin Oncol 28:e461-463

21. Lewis JS Jr, Spence DC, Chiosea S, Barnes EL Jr, BrandweinGensler M, El-Mofty SK (2010) Large cell neuroendocrine carcinoma of the larynx: definition of an entity. Head Neck Pathol 4:198-207

22. Trabka-Zawicki P, Składzień J, Zawiliński J, Wierzchowski W (2002) Diagnostic difficulties in neuroendocrine carcinoma of the larynx. Otolaryngol Pol 56:433-435 (Article in Polish)

23. Hallaoui Y, El Kohen A, Sefiani S, Benchekroun L, Jazouli N, Kzadri M (2004) Laryngeal neuroendocrine carcinoma: a case report. Rev Laryngol Otol Rhinol (Bord) 125:229-232 (Article in French)

24. Halmos GB, van der Laan TP, van Hemel BM, Dikkers FG, Slagter-Menkema L, van der Laan BF, Schuuring E (2013) Is human papillomavirus involved in laryngeal neuroendocrine carcinoma? Eur Arch Otorhinolaryngol 270:719-725

25. Larsson LG, Donner LR (1999) Large cell neuroendocrine carcinoma of the parotid gland: fine needle aspiration, and light microscopic and ultrastructural study. Acta Cytol 43:534-536

26. Xu L, Guan B, Peng X, Xu Y, Wang Y, Wu J (2013) Analysis on 6 cases with nasal neuroendocrine carcinoma. Lin Chung Er Bi Yan Hou Tou Jing Wai Ke Za Zhi 27:236-238 (Article in Chinese)

27. Krishnamurthy A, Vaidhyanathan A, Majhi U (2011) Large cell neuroendocrine carcinoma of the retromolar trigone. J Cancer Res Ther 7:343-346

28. Kusafuka K, Asano R, Kamijo T, Iida Y, Onitsuka T, Kameya T, Nakajima T (2009) Large cell neuroendocrine carcinoma of the tongue base: case report of an unusual location with immunohistochemical analysis. Int J Oral Maxillofac Surg 38:296-299

29. Kawaratani H, Tsujimoto T, Yoshikawa M, Kawanami F, Shirai Y, Yoshiji H, Morita K, Fukui H (2013) Large cell neuroendocrine carcinoma presenting with neck swelling in the submandibular gland: a case report. J Med Case Rep 7:81

30. Bari MF, Brown H, Nicholson AG, Kerr KM, Gosney JR, Wallace WA, Soomro I, Muller S, Peat D, Moore JD, Ward LA, Freidin MB, Lim E, Vatish M, Snead DR (2014) BAI3, CDX2 and VIL1: a panel of three antibodies to distinguish small cell from large cell neuroendocrine lung carcinomas. Histopathology 64:547-556

31. Niho S, Kenmotsu H, Sekine I, Ishii G, Ishikawa Y, Noguchi M, Oshita F, Watanabe S, Nakajima R, Tada H, Nagai K (2013) Combination chemotherapy with irinotecan and cisplatin for large-cell neuroendocrine carcinoma of the lung: a multicenter phase II study. J Thorac Oncol 8:980-984 